\title{
Estimation of Irrigation Scheduling for Different Cropping Pattern at Different Growth Stage of Crop by using the CROPWAT Model
}

\author{
Shashank Shekhar ${ }^{1 *}$, Alpna Dubey ${ }^{2}$ and Chwadaka Pohshna ${ }^{3}$ \\ ${ }^{1}$ Collage of Agricultural Engineering, Bapatla, Andra Pradesh, India \\ ${ }^{2}$ Jawaharlal Nehru Krishi Vishwa Vidyalaya, Jabalpur, Madhya Pradesh, India \\ ${ }^{3}$ Collage of Agricultural Engineering and Post-Harvest Technology Ranipool, Sikkim, India \\ *Corresponding author
}

\section{A B S T R A C T}

\begin{tabular}{|l|}
\hline K e y w o r d s \\
Irrigation, Cropping \\
Pattern, Growth \\
Stage, CROPWAT \\
Model
\end{tabular}

\section{Introduction}

Rice is the stable food for all most half of the world population. The rice crop approximately consumes two to five time more water as compare to other cereal crop. In northern India next to rice cotton crop also consider a major crop. In traditional rice method, $5-15 \mathrm{~cm}$ of standing water was maintained throughout the rice growing season and consume $50-300 \mathrm{~cm}$ to total seasonal water (Bouman and Tuong, 2001). Whereas, 60-90 $\mathrm{cm}$ of water applied throughout the growing season for cotton crop (Sankaranarayanan et al., 2007). The global irrigation water is declining with increasing the demand of water due to growing population for various purpose such as industrial, agriculture hydropower. The irrigation practice uses about $80 \%$ of the total available water resource of the area, out of which $70 \%$ of irrigation water is lost as deep percolation, because of poor management practices and only $30 \%$ of water was used by plant (Feng et al., 2007). Whereas, Shah et al., (2015) documented that about $40-60 \%$ of water used by plant and rest of water lost from the field (evapotranspiration, deep percolation, etc.). The production can be increased by improving the irrigation scheduling method. Increase the crop production with these 
limited water resource is the challenge for coming decades. Therefore, there is a need to modified traditional irrigation scheduling.

A well management of irrigation water involves precise irrigation scheduling which involves when to irrigate and how much to irrigate. The proper irrigation scheduling promote application of water at right time with right quantity in order to improve water use efficiency and productivity. Insufficient irrigation or over irrigation could be responsible to reduce crop yields, quality, and poor nutrient use efficiency (Shah et al., 2015). However, accurate estimation of the crop water requirement is necessary to determine when and how much to irrigate. The irrigation scheduling plays a major role to increase the water use efficiency. Jones (2004) documented that slight moisture deficiency of plant (irrigation scheduling) can improves the plant growth and plant productivity. But irrigation scheduling still has been not widely adopted: many of these are based on sensing the plant response to water deficits rather than sensing the soil moisture status directly (Jones, 1990: Jones, 2004).

The water use efficiency can be increased by optimizing three factor such as specific amount of water applied, timing of the application, and efficiency of the irrigation method. Shah et al., (2015) documented that about $40-60 \%$ of water used by plant and rest of water lost from the field (evapotranspiration, deep percolation, etc). These water losses can be minimized by irrigation scheduling. The irrigation scheduling is important to understand the behavior of crop growth and productivity with water flow. Mathematical models could be a good tool to understand the crop behavior and to decide when to irrigate and how much to irrigate without conducting expensive and time-consuming field experiments. The CROPWAT model is an irrigation management tool which is based on crop, soil and climate parameters (major parameters). The CROPWAT model was devolved by the Land and Water Development Division of Food and Agriculture Organization of the United States. CROPWAT model estimates the reference evapotranspiration, crop evapotranspiration, irrigation scheduling, and agricultural water requirements for different crops (Nazeer, 2009). The crop evapotranspiration, crop water requirement and scheduling are difficult to obtained during the field experiment. Therefore, irrigation scheduling model is necessary to increase the irrigation efficiency and crop productivity. The objective of the study was to analyze the reference evapotranspiration and effective rainfall for the study area and to simulate the irrigation scheduling for rice and cotton crop by using CROPWAT model.

\section{Materials and Methods}

\section{Study area}

The study area comprises of Lucknow district, Utter Pradesh, India (Fig. 1), the site receives average annual rainfall of $992 \mathrm{~mm}$. The average maximum and minimum temperature was 19.4 and $32.3^{\circ} \mathrm{C}$, respectively. The average annual wind speed, humidity and radiation were $52 \mathrm{~km} /$ day, $58 \%$ and 18.5 $\mathrm{MJ} / \mathrm{m}^{2} /$ day, respectively.

\section{Data collection}

The meteorological data such as rainfall, maximum and minimum temperature, wind speed, humidity, sunshine hour and radiation was collected from the customized rainfall information system (CRIS), climate data website and climate2.0for CROPWAT model. The crop and soil parameter initially taken from the publish literature (Ko et al., 2009; Montazar et al., 2017; Gill et al., 2017) and optimized during the modeling. 


\section{CROPWAT modeland setup}

CROPWAT model (Smith, 1992) is a decision supporting tool developed by water development division of FAO in computer programing language for calculating crop water requirement using soil, crop and climatic data.

\section{Reference evapotranspiration}

Penman-Monteith equation was used in CROPWAT model for calculating daily reference evapotranspiration $\left(\mathrm{ET}_{\mathrm{o}}\right)$. The daily reference evapotranspiration (Allen et al., 2006) was expressed by:

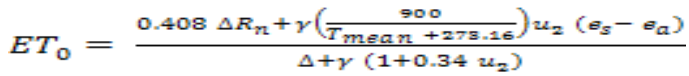

Where, $R_{n \text { is }}$ the net radiation at the crop surface $\left(\mathrm{MJ} / \mathrm{m}^{2} /\right.$ day), ${ }^{\text {mean }}$ is the mean of the daily maximum and minimum temperature $\left({ }^{\circ} \mathrm{C}\right),{ }_{2}$ is the wind speed at slandered $2 \mathrm{~m}$ height $(\mathrm{m} / \mathrm{s}), e_{s}$ is the saturation vapor pressure $(\mathrm{kPa}), e_{\alpha}$ is actual vapor pressure $(\mathrm{kPa}), \Delta$ is the slope of vapor pressure curve $\left(\mathrm{kPa} /{ }^{\circ} \mathrm{C}\right)$, and $\gamma$ is the psychrometric constant $\left(\mathrm{kPa} /{ }^{\circ} \mathrm{C}\right)$.

\section{Effective rainfall}

The CROPWAT model determines the effective rainfall based on rainfall data. The effective rainfall is a portion of rainfall which is effectively used by plant. This effective rainfall was used to determine the irrigation requirement. The effective rainfall was determining by based on four methods, which is expressed as:

\section{Fixed percentage method}

In this method some threshold value was fixed to decide an effective rainfall.
Dependable rainfall

Effective rainfall $=0.6 \times$ rainf all $-10 / 30 \quad$ for rainf all $\leq 70 / 3 \mathrm{~mm}$ (2)

Effective rainf all $=0.8 \times$ rainfall $-24 / 30 \quad$ for rainfall $>70 / 3 \mathrm{~mm}$

Empirical formula

Effective rainfall $=0.5 \times$ rainf all $+0.5 / 3$ for rainfall $\leq 50 / 3 \mathrm{~mm}$ (4)

Effective rainfall $=0.7 \times$ rainf all $+\frac{20}{3} \quad$ for rainfall $>50 / 3 \mathrm{~mm}$

USDA soil conservation service

Effective rainfall $=($ rainfall $\times(125-0.2 \times 3 \times$ rainfall $)) / 125$ for rainfall $\leq$

$250 / 3 \mathrm{~mm}$

Effective rainfall $=125 / 3+0.1$ x rainfallforrainf all $\leq 250 / 3 \mathrm{~mm}$ (7)

\section{Crop and soil parameter}

The crop and soil parameters such as crop coefficient, root length, ponding depth, transplanting date, harvesting date, field capacity, permanent welting point were given as an input shown in Figure 2. These inputs also play an important role to decide an irrigation interval or crop water requirement.

\section{Crop pattern}

During the present manuscript the pattern of crop was selected rice and cotton for estimation of irrigation scheduling or crop water requirement.

\section{Results and Discussion}

\section{Effective rainfall}

Figure 3 shows variation of effective rainfall and rainfall with time. It evident from the Figure 3 that rainfall was less in non-rainy season (month of Nov-May) as compare to rainy season. Therefore, during the non-rainy season effective rainfall was almost equal to the rainfall due to less runoff, deep percolation, and seepage losses. Whereas, in 
rainy season the effective rainfall was $7-49 \%$ less as compare to the rainfall due to the more losses.

\section{Reference evapotranspiration}

Figure 4 shows variation of reference evapotranspiration with time. The reference evapotranspiration was minimum in January and February month, and reached its peak during the month of March-October and further decline during the month of November and December. The reference evapotranspiration was varied from 1.8 (January) to 6.08 (May) $\mathrm{mm} /$ day presented in Figure 4. It is evident from the Figure $4 \mathrm{a}$ and $4 \mathrm{~b}$, the reference evapotranspiration was directly proportional to the radiation and sunshine hours. Whereas, it was inversely proportional to the relative humidity (Fig. 4d). From the Figure 4e and 4f, it is shown that the evapotranspiration was linearly increased with increase in temperature up to June month and then further decreased randomly due to the maximum variation of sunshine hour and radiation.

\section{Irrigation requirement}

Table 1 shows the variation of crop evapotranspiration and irrigation requirement with time for rice and cotton crop. It is evident from the Table 1 that crop evapotranspiration (ETc) was less at initial stage, increased at the mid stage and declined at late stage. Shah et al., 2015 had also reported that the crop evapotranspiration (ETc) was less at initial stage, increased at the mid stage and declined at late stage. The crop evapotranspiration was followed the same pattern as reference evapotranspiration (Fig. 4). It is also evident from the Table 1 that irrigation was applied, when there was less or no rainfall. The crop evapotranspiration, effective rainfall and the crop water requirement varied from $0.74-5.57$ $\mathrm{mm} /$ day, $0.1-55.1 \mathrm{~mm} / \mathrm{dec}$ and $0-157 \mathrm{~mm} / \mathrm{dec}$, respectively (Table 1).

Table.1 Variation of crop evapotranspiration and irrigation requirement for rice and cotton crop

\begin{tabular}{|c|c|c|c|c|c|c|c|c|c|}
\hline \multicolumn{5}{|c|}{ Rice } & \multicolumn{5}{|c|}{ Cotton } \\
\hline $\begin{array}{c}\text { Month } \\
\text { (Decade) }\end{array}$ & $\mathbf{K}_{\mathbf{c}}$ & $\begin{array}{l}\mathbf{E t}_{\mathbf{c}}, \\
\mathbf{m m} / \text { day }\end{array}$ & $\begin{array}{l}\text { Effective } \\
\text { rain, } \\
\mathrm{mm} / \mathrm{dec}\end{array}$ & $\begin{array}{l}\text { Irrigation } \\
\text { Requirement, } \\
\text { mm/dec }\end{array}$ & $\begin{array}{l}\text { Month } \\
\text { (Decade) }\end{array}$ & $\mathbf{K}_{\mathrm{c}}$ & $\begin{array}{l}\mathbf{E t}_{\mathrm{c}}, \\
\mathrm{mm} / \mathrm{day}\end{array}$ & $\begin{array}{l}\text { Effective } \\
\text { rain, } \\
\text { mm/dec }\end{array}$ & $\begin{array}{l}\text { Irrigation } \\
\text { Requirement, } \\
\text { mm/dec }\end{array}$ \\
\hline Jun (1) & 1.05 & 0.74 & 11.3 & 0 & $\operatorname{Jul}(2)$ & 0.31 & 1.13 & 27.6 & 0 \\
\hline $\operatorname{Jun}(2)$ & 1.05 & 4.14 & 26.3 & 157 & $\operatorname{Jul}(3)$ & 0.31 & 1.12 & 54 & 0 \\
\hline $\operatorname{Jun}(3)$ & 1.05 & 5.57 & 34.8 & 121 & $\operatorname{Aug}(1)$ & 0.31 & 1.14 & 52.5 & 0 \\
\hline Jul(1) & 1.05 & 4.76 & 45.6 & 1.9 & $\operatorname{Aug}(2)$ & 0.35 & 1.25 & 52.9 & 0 \\
\hline $\operatorname{Jul}(2)$ & 1.1 & 4.01 & 55.1 & 0 & $\operatorname{Aug}(3)$ & 0.54 & 1.97 & 49.6 & 0 \\
\hline $\operatorname{Jul}(3)$ & 1.1 & 3.99 & 54 & 0 & $\operatorname{Sep}(1)$ & 0.73 & 2.77 & 47.9 & 0 \\
\hline $\operatorname{Aug}(1)$ & 1.1 & 4.05 & 52.5 & 0 & $\operatorname{Sep}(2)$ & 0.92 & 3.58 & 46.1 & 0 \\
\hline $\operatorname{Aug}(2)$ & 1.1 & 3.96 & 52.9 & 0 & $\operatorname{Sep}(3)$ & 1.1 & 4.18 & 34.9 & 7 \\
\hline $\operatorname{Aug}(3)$ & 1.11 & 4.08 & 49.6 & 0 & $\operatorname{Oct}(1)$ & 1.16 & 4.28 & 20.9 & 21.9 \\
\hline $\operatorname{Sep}(1)$ & 1.11 & 4.19 & 47.9 & 0 & $\operatorname{Oct}(2)$ & 1.16 & 4.17 & 9.9 & 31.8 \\
\hline $\operatorname{Sep}(2)$ & 1.11 & 4.3 & 46.1 & 0 & $\operatorname{Oct}(3)$ & 1.16 & 3.76 & 6.7 & 34.7 \\
\hline $\operatorname{Sep}(3)$ & 1.11 & 4.2 & 34.9 & 7.1 & $\operatorname{Nov}(1)$ & 1.16 & 3.35 & 0.9 & 32.6 \\
\hline $\operatorname{Oct}(1)$ & 1.09 & 4.03 & 20.9 & 19.4 & $\operatorname{Nov}(2)$ & 1.16 & 2.94 & 0 & 29.4 \\
\hline $\operatorname{Oct}(2)$ & 1.04 & 3.74 & 9.9 & 27.5 & $\operatorname{Nov}(3)$ & 1.14 & 2.63 & 0.2 & 26.2 \\
\hline $\operatorname{Oct}(3)$ & 0.98 & 3.19 & 6.7 & 28.4 & $\operatorname{Dec}(1)$ & 1.02 & 2.14 & 1.1 & 20.3 \\
\hline \multirow[t]{4}{*}{$\operatorname{Nov}(1)$} & 0.95 & 2.75 & 0.1 & 2.7 & $\operatorname{Dec}(2)$ & 0.9 & 1.68 & 1.4 & 15.3 \\
\hline & & & & & $\operatorname{Dec}(3)$ & 0.77 & 1.42 & 3.5 & 12.1 \\
\hline & & & & & $\operatorname{Jan}(1)$ & 0.64 & 1.16 & 6.5 & 5.1 \\
\hline & & & & & $\operatorname{Jan}(2)$ & 0.57 & 1.02 & 0.9 & 1 \\
\hline
\end{tabular}


Table.2 Variation of irrigation scheduling with time

\begin{tabular}{|c|c|c|c|c|c|c|c|c|c|c|c|c|c|}
\hline \multicolumn{2}{|c|}{ Precipitation deficit } & Jan & Feb & Mar & Apr & May & Jun & Jul & Aug & Sep & Oet & Nov & Dec \\
\hline \multicolumn{2}{|l|}{ Rice } & 0 & 0 & 0 & 0 & 0 & 140.7 & 143.3 & 21.2 & 7.1 & 79.7 & 19.5 & 0.0 \\
\hline \multicolumn{2}{|c|}{ COTTON } & 3.3 & 0 & 0 & 0 & 0 & 0.0 & 0.0 & 0.0 & 6.9 & 87.4 & 86.8 & 44.5 \\
\hline \multirow{3}{*}{$\begin{array}{l}\text { Net } \\
\text { scheme } \\
\text { irr.req. }\end{array}$} & (mm/day) & 0.1 & 0 & 0 & 0 & 0 & 2.3 & 2.3 & 0.6 & 0.2 & 2.7 & 1.8 & 0.7 \\
\hline & (mm/month) & 1.7 & 0 & 0 & 0 & 0 & 70.4 & 71.6 & 18.0 & 7.0 & 83.6 & 53.1 & 22.3 \\
\hline & $(1 / \mathrm{s} / \mathrm{h})$ & 0.01 & 0 & 0 & 0 & 0 & 0.2 & 0.2 & 0.1 & 0.03 & 0.3 & 0.2 & 0.1 \\
\hline \multicolumn{2}{|c|}{ Irr.req. for actual area, (l/s/h) } & 0.01 & 0 & 0 & 0 & 0 & 0.54 & 0.53 & 0.06 & 0.03 & 0.31 & 0.2 & 0.17 \\
\hline
\end{tabular}

Fig.1 Location map of study area

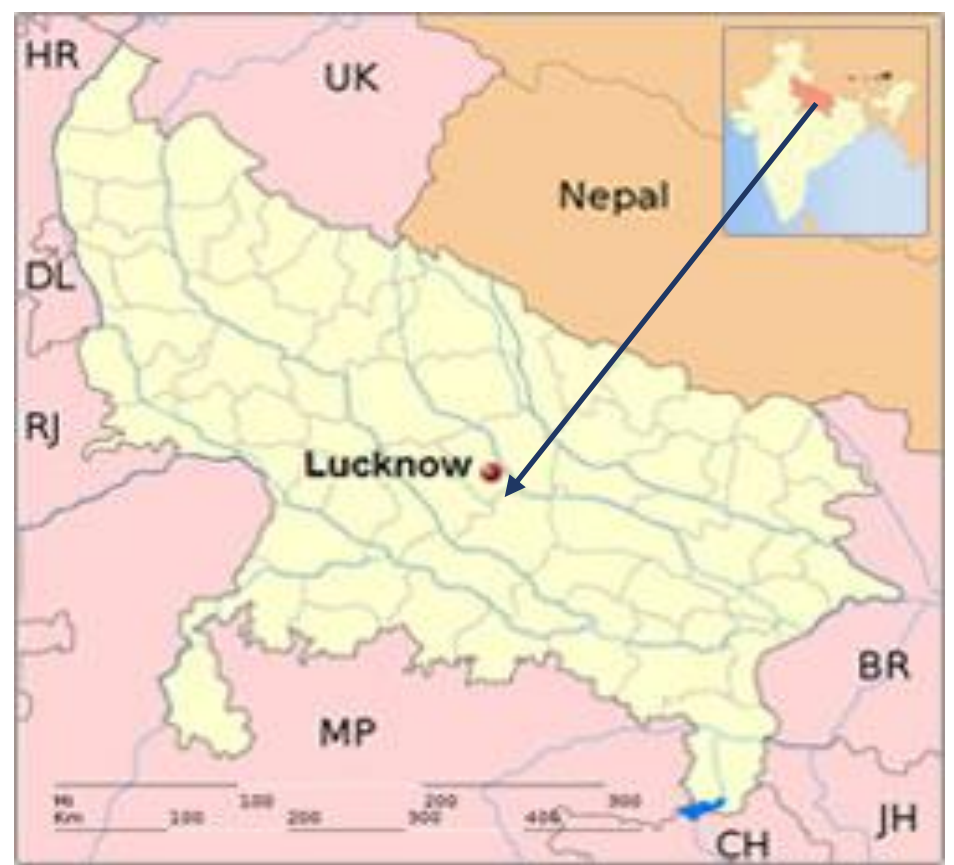

Fig.2 Crop and soil parameter with different growth stage

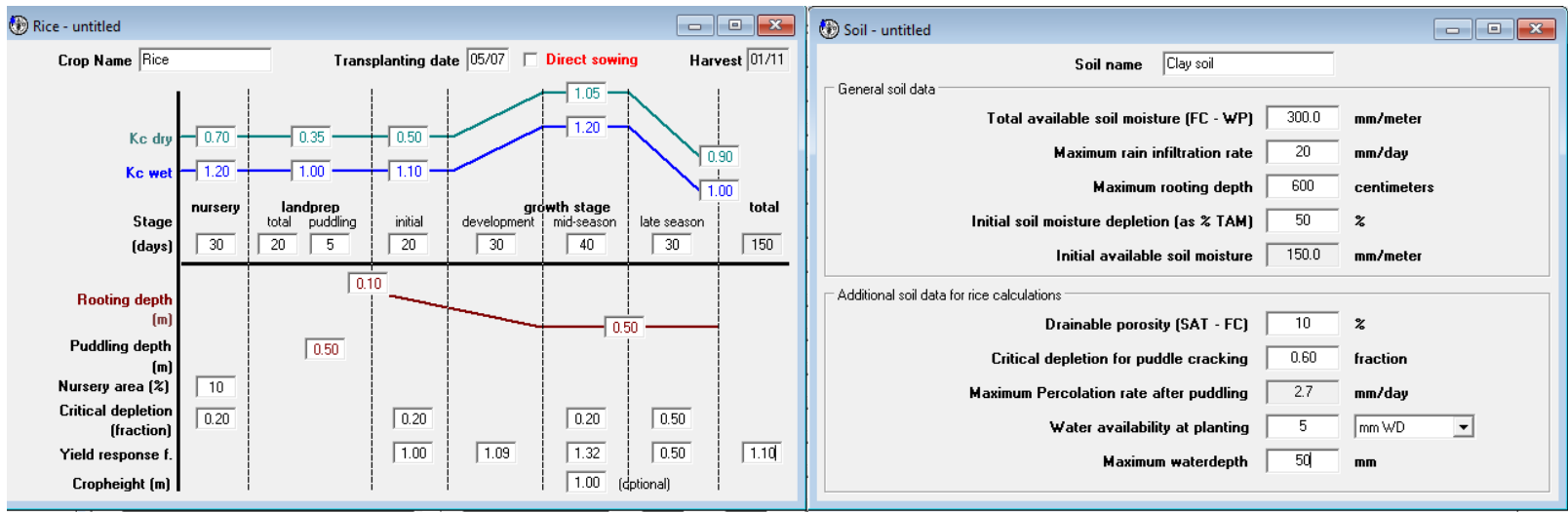


Fig.3 Monthly variation of effective rainfall and rainfall

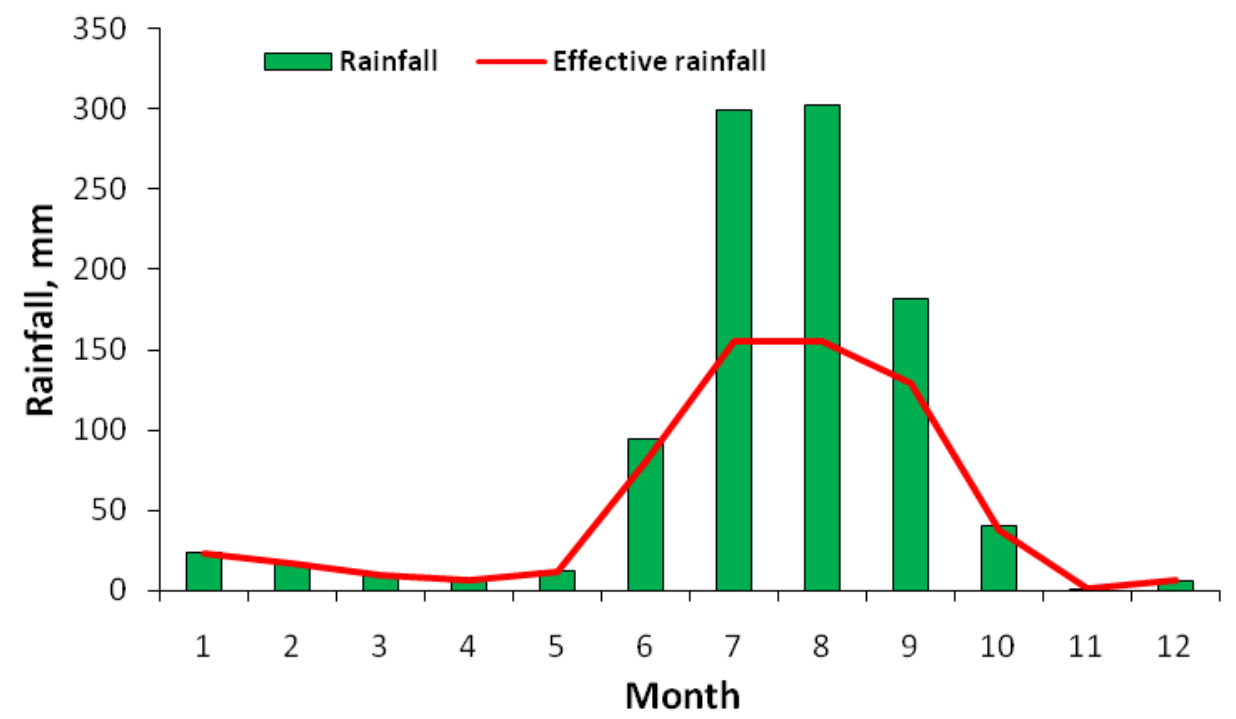

Fig.4 Monthly variation of evapotranspiration with (a) sunshine hour (b) radiation (c) wind speed (d) relative humidity (e) minimum temperature (f) maximum temperature
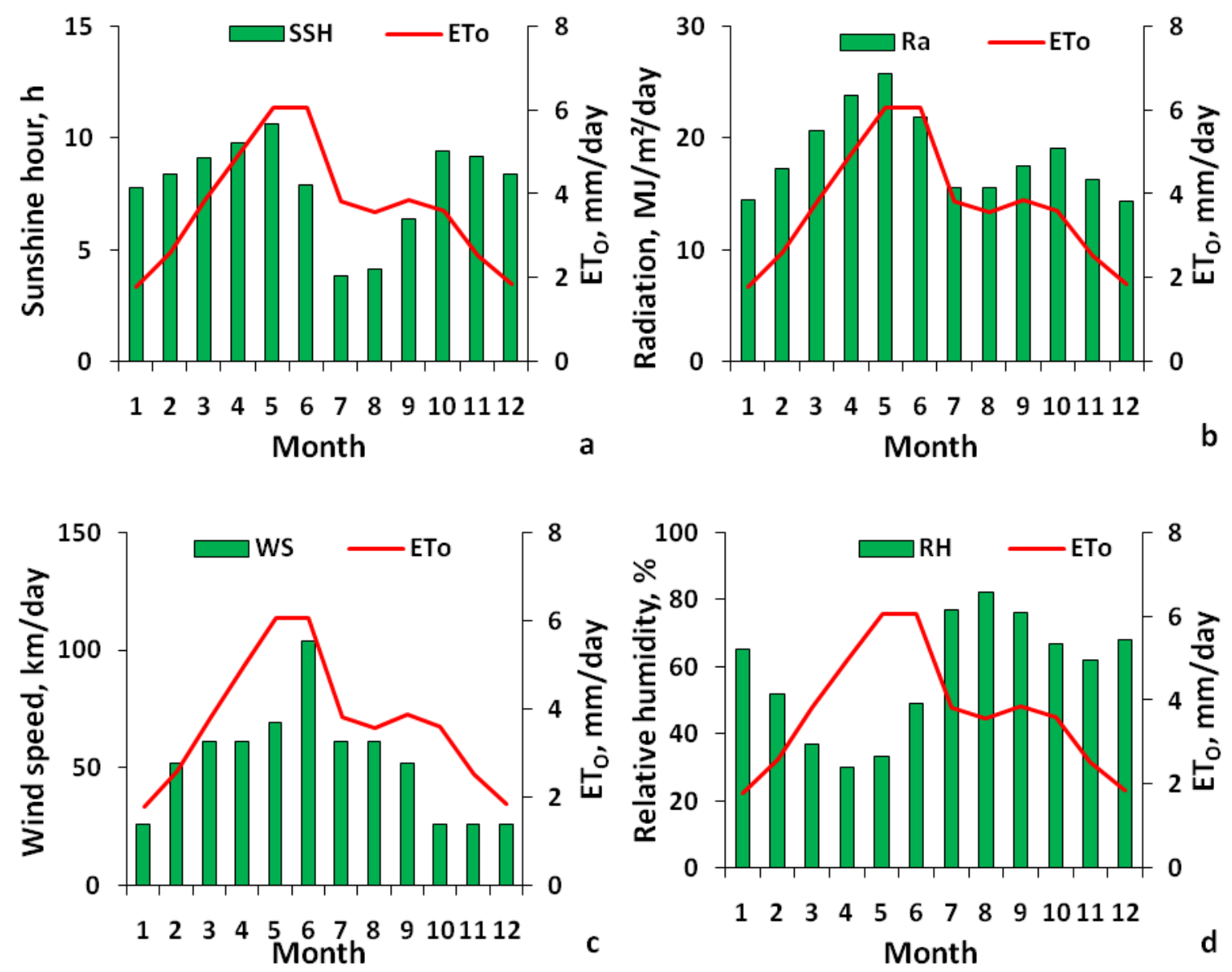




\section{Irrigation scheduling}

The estimation of actual irrigation scheduling was carried out for rice and cotton crop (Table 2). The total amount of water was applied for the $1000 \mathrm{~mm}$ (irrigation: $400 \mathrm{~mm}$ and rainfall: $600 \mathrm{~mm}$ ) and $129 \mathrm{~mm}$ (irrigation: $29 \mathrm{~mm}$ and rainfall: $100 \mathrm{~mm}$ ) for rice and cotton crop, respectively. The amount of water requirement for rice crop was higher but realistic because the rice crop was having the continuous standing water throughout the growing season. The irrigation water was applied for lowland rice was particularly lower because maximum water was taken by rice crop from rainfall. The irrigation water requirement was varied from 1.7-83.6 $\mathrm{mm} / \mathrm{month}$ (Table 2).

The healthy crop required a best irrigation scheduling which could be calculated by using a mathematical model. In this study the CROPWAT model was used to estimate the irrigation scheduling for rice and cotton crop. The analysis of the reference evapotranspiration was almost directly proportional to the radiation and sunshine hours and inversely proportional to the relative humidity. The reference evapotranspiration was varying from 1.8 (January) to 6.0 (May) $\mathrm{mm} /$ day. Whereas, the crop evapotranspiration, effective rainfall and the crop water requirement varied from 0.74



to $5.57 \mathrm{~mm} / \mathrm{day}, 0.1$ to $55.1 \mathrm{~mm} / \mathrm{dec}$ and 0 to $157 \mathrm{~mm} / \mathrm{dec}$, respectively. CROPWAT model appropriately estimate the reference evapotranspiration, effective rainfall and other parameter for irrigation scheduling, which makes this model as a best tool for irrigation planning and management for all the crop and climatic condition.

\section{References}

Bekele, S. and Tilahun, K. 2007. Regulated deficit irrigation scheduling of onion in a semiarid region of Ethiopia. Agricultural Water Management, 89(1-2), pp. 148-152.

Bouman, B.A.M., and Tuong, T.P. (2001). "Field water management to save water and increase its productivity in irrigated lowland rice". Agricultural Water Management, 49(1), pp. 11-30.

Climate data: https://en.climate-data.org/ location/2850/

CRIS (customized rainfall information system), Hydromet division. http:// hydro.imd.gov.in/hydrometweb/(S(bsvy gq45npgsxp55inwonu35))/DistrictRaifa 11.aspx

FAO (Food and Agriculture Organization), 2002. Deficit irrigation practices. Water Report No. 22.

Feng, Z., Liu, D. and Zhang, Y., 2007. Water requirements and irrigation scheduling 
of spring maize using GIS and Crop Wat model in Beijing-Tianjin-Hebei region. Chinese Geographical Science, 17(1), pp. 56-63.

Gill, K., J., K.K., Kaur, S. and Aggarwal, R., 2017. Estimation of crop coefficient for rice and wheat crops at Ludhiana. Journal of Agrometeorology, 19(2), pp. 170-171.

Jones, H.G. 1990. Plant water relations and implications for irrigation scheduling. Acta Horticulturae 278, 67-76.

Jones, H.G. 2004. Irrigation scheduling: advantages and pitfalls of plant-based methods. Journal of experimental botany, 55(407), pp. 2427-2436.

Ko, J., Piccinni, G., Marek, T. and Howell, T., 2009. Determination of growth-stagespecific crop coefficients $(\mathrm{Kc})$ of cotton and wheat. Agricultural Water Management, 96(12), pp. 1691-1697.

Montazar, A., Rejmanek, H., Tindula, G., Little, C., Shapland, T., Anderson, F., Inglese, G., Mutters, R., Linquist, B., Greer, C.A. and Hill, J., 2017. Crop coefficient curve for paddy rice from residual energy balance calculations.
Journal of Irrigation and Drainage Engineering, 143(2), p. 04016076.

Nazeer, M. 2009. Simulation of maize crop under irrigated and rainfed conditions with CROPWAT model. ARPN Journal of Agricultural and Biological Science. VOL. 4, NO. 2, MARCH 2009 ISSN 1990-6145 www.arpnjournals.com

Sankaranarayanan, K., Praharaj, C.S., and Bandyopadhyay, K.K., 2007. Water management practices to improve cotton production. Model training course "Cultivation of long staple cotton (ELS); Central Institute of Cotton Research, Coimbatore.

Shah, P.V., Mistry, R.N., Amin, J.B., Parmar A.M., Shaikh, Moh. R.A. 2015 Irrigation Scheduling Using CROPWAT. International Journal of Advance Research in Engineering, Science \& Technology (IJAREST), 2 (4), pp 1-10.

Smith, M., 1992. CROPWAT: A computer program for irrigation planning and management (No. 46). Food \& Agriculture Org.

\section{How to cite this article:}

Shashank Shekhar, Alpna Dubey and Chwadaka Pohshna. 2018. Estimation of Irrigation Scheduling for Different Cropping Pattern at Different Growth Stage of Crop by using the CROPWAT Model. Int.J.Curr.Microbiol.App.Sci. 7(08): 3855-3862. doi: https://doi.org/10.20546/ijcmas.2018.708.395 